in the Summer of r906, when he hinted at his fears that he might not live to see the completion of his task.

Still, a scholar's work lies in teaching as well as in writing; and it was to teaching that Professor Warren devoted all his energy. On his return from Germany he was appointed to the responsible post of Latin Professor at the newly-founded centre of research, the Johns Hopkins University. ' In 1896-97, he was director of the American School of Classical Studies in Rome, where, by a happy coincidence, Professor Kauer was engaged in his re-collation of the Bermbine Terence in the Vatican Library. In 1899 he was called to the University of Harvard. At all three places, Baltimore, Rome, and Boston, his success in teaching advanced students was equalled only by the affection with which his pupils regarded him. As his Harvard colleague, Prof. Wright, has said of him, 'no American Latinist. can point to a larger number than could he of able and productive scholars in his own field, who, if not members of his "school," at least owed to him their-inspiration and their method.' He married in 1885 Miss Salomé A. Machado of Salem, Mass., who, with a son and a daughter, survives him.

W. M. LINDSAY.

\title{
ALFRED PRETOR.
}

DiED at Wyke, near Weymouth, on January 8, Alfred Pretor, formerly head boy of Harrow, scholar of Trinity College, and for thirty-five years fellow of S. Catharine's College.

Amongst the instructors of his youth may be mentioned the names of C. J. Vaughan, B. F. Westcott, J. B. Lightfoot, and F. A. Paley, with all of whom he maintained to the last an unbroken friendship.
He was a sound scholar of the old type, a ready composer, fluent translator, and stimulating teacher. His chief works were editions of Persius (a second edition in 1907); Sophocles' Trachiniae, Xenophon's Anabasis;, Cicero ad Atticum I- and II, and 'Exercises in Translation at sight.' As a writer of short stories he was singularly successful.

\section{A. W. S.}

\section{REPORTS}

\section{GRAVES NEAR 'WAR DITCHES,' CHERRY-HINTON, CAMBRIDGE.}

During the spring of 1907, at the instance of Prof. T. Mc Kenny Hughes, three skeletons were disinterred, by the writer, from graves outside the "War Ditches;' which lie on a spur of the GogMagog Hills at Cherryhinton.

The graves, which bad rounded ends, were hollowed out of the disintegrated chalk; the bottom of each grave was $3 \mathrm{ft}$. below grass level.

The three skeletons were pronounced by Prof. Macalister and Dr. Duckworth to be of the PreRoman East-Anglian type like many that were discovered in 1903 by Prof, Hughes, near, and in, the - War Ditches.'
The chief interest lies in grave No, 1 . Within the crook of the right arm of the skeleton was found a small, but complete, Roman pot, thus :-

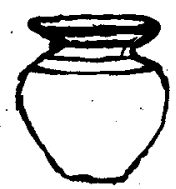

5 in. in height and 4 in. in diameter across the rim. It contained only chalk rubble. No coinsfor metal were found with these skeletons 